\title{
Response of Phosphorus Application on Productivity of Wheat at Farmer Field
}

\author{
B. S. Dwivedi ${ }^{1, *}$, Abhishek Sharma ${ }^{1}$, A. K. Dwivedi ${ }^{1}$, R. K. Thakur ${ }^{2}$ \\ ${ }^{1}$ Department of Soil Science and Agricultural Chemistry, Jawaharlal Nehru Krishi Vishwa Vidyalaya, India \\ ${ }^{2}$ College of Agriculture, Waraseoni (Balaghat) Jawaharlal Nehru Krishi Vishwa Vidyalaya, India
}

Copyright $(02019$ by authors, all rights reserved. Authors agree that this article remains permanently open access under the terms of the Creative Commons Attribution License 4.0 International License

\begin{abstract}
Wheat (Triticum aestivum L.) is one of most important rabi cereal crop of northern Madhya Pradesh in India. The availability of phosphorus in the soil for plant utilization is known to be affected not only by the inherent soil characteristics but also by the fertilizer use and management practices followed for crop production. Therefore, a study on the response of phosphorus on farmer field for improving wheat productivity was performed at Jabalpur, India. In between the technology intervention HRD components were also included to excel the farmers understanding and skill about the demonstrated technology on nutrient management aspects. The front line demonstration conducted at six farmer's field of village's viz. Luhari, Gathora, Ghatera, Kanthi and Gurda pipariya on wheat (variety GW-366) during Rabi 2015-16. The soil contained $\mathrm{pH} 6.5$ to 7.2 , EC 0.16 to $0.21 \mathrm{dSm}^{-1}$, organic carbon 0.49 to $0.69 \%$, available nitrogen 204 to $254 \mathrm{Kg}$ $\mathrm{ha}^{-1}$, phosphorus 7.1 to $16.2 \mathrm{Kg} \mathrm{ha}^{-1}$ and potassium 411 to $470 \mathrm{Kg} \mathrm{ha}^{-1}$. The experiment included 5 treatments viz., $\mathrm{T}_{1}$ $100 \%$ NPK +5 t FYM ha $^{-1}, \mathrm{~T}_{2}-100 \%$ NPK, $\mathrm{T}_{3}-100 \%$ $\mathrm{NK}+50 \% \mathrm{~K}, \mathrm{~T}_{4}-100 \% \mathrm{NPK}-(\mathrm{S})$ and $\mathrm{T}_{5}-$ farmer's practice. The result indicated that the treatment $\mathrm{T}_{1}-100 \%$ NPK +FYM produced the highest average yield of wheat. The lowest yield was recorded in $\mathrm{T}_{5}$-farmer's practice. The highest increase in yield (26\%) was observed with $100 \%$ NPK + FYM over farmer's practice, followed by $13 \%$ increase in yield $(100 \%$ NPK) of wheat over farmer's practice.
\end{abstract}

Keywords Wheat, Phosphorus, Manure, Yields

\section{Introduction}

Wheat (Triticum aestivum L.) is one of most important rabi cereal crops of northern Madhya Pradesh, India. Approximately 95 percent of wheat grown in the world is hexaploid bread wheat (Triticum aestivum, L.), used for a wide range of baked goods, including bread, cookies, cakes and biscuit, with most of the remaining about 5 percent being tetraploid durum wheat (Triticum durum, Desf.) commonly used for pasta and noodles etc. Protein content and composition is a critical quality factor in the production of these products [10]. It is cultivated in an area of 30.72 mha in India with an annual production of 97.44 $\mathrm{mt}$ and average productivity of $3172 \mathrm{~kg} \mathrm{ha}^{-1}$. Whereas in Madhya Pradesh it is being cultivated in 5.94 mha of land with its annual production $17.78 \mathrm{mt}$ and average productivity of $2993 \mathrm{~kg} \mathrm{ha}^{-1}$ [2]. The availability of phosphorus in the soil for plant utilization is known to be affected not only by the inherent soil characteristics but also by the fertilizer use and cropping practices followed [11]. It has been observed in black soil that a major part of the applied phosphorus gets fixed (80-85\%) and only a small part (15-20\%) of it becomes available to the crop plants [12]. Keeping in view the above facts, the present investigation was undertaken.

\section{Materials and Methods}

The present study is a part of the ongoing All India Coordinated Research Project on Long Term Fertilizer Experiment at Madhya Pradesh, India. The location of investigation was Jabalpur district of Madhya Pradesh, India. The study area has a semi-arid and sub-tropical climate with a characteristic feature of dry summer and cold winter. In winter season i.e. from November to February months, the temperature ranges from 4 to $33^{\circ} \mathrm{C}$ and the relative humidity varies from 70 to $90 \%$. Dry and warm weather usually prevails during the months of March to June. The temperature in the month of May rise as high as $46^{\circ} \mathrm{C}$. Monsoon season extends from mid-June to mid-September. The temperature during this period ranges from 25 to $35^{\circ} \mathrm{C}$ and the relative humidity ranges between 70 to $80 \%$. The total annual rainfall varies from 1400 to $1500 \mathrm{~mm}$ with the mean value of around $1400 \mathrm{~mm}$.

Participatory rural appraisal (PRA), group discussion and transect walk were followed to explore the detail 
information of study area. In between the technology intervention HRD components (Trainings/ soil health camp/ field day etc.) were also included to excel the farmers understanding and skill about the demonstrated technology on nutrient management. The front line demonstration conducted at six farmer's field of adopted villages viz. Luhari, Gathora, Ghatera, Kanthi and Gurda pipariya on wheat (varietyGW-366) during Rabi 2015-16. Information on soil condition of the fields used in this experiment was as follows; $\mathrm{pH} 6.5$ to 7.2 , EC 0.16 to 0.21 $\mathrm{dSm}^{-1}$, organic carbon 0.49 to $0.69 \%$, available nitrogen 204 to $254 \mathrm{~kg} \mathrm{ha}^{-1}$, phosphorus 7.1 to $16.2 \mathrm{ha}^{-1}$ and potassium 411 to $470 \mathrm{~kg} \mathrm{ha}^{-1}$. The experiment included 5 treatments viz., $\mathrm{T}_{1}-100 \% \mathrm{NPK}+5 \mathrm{t} \mathrm{FYM} \mathrm{ha}^{-1}, \mathrm{~T}_{2}-100 \%$ $\mathrm{NPK}, \mathrm{T}_{3}-100 \% \mathrm{NK}+50 \% \mathrm{~K}, \mathrm{~T}_{4}-100 \% \mathrm{NPK}-(\mathrm{S})$ and $\mathrm{T}_{5}$ - farmer's practice (table 1). Extension and technological gaps were also calculated.

Table 1. Information regarding experiment

\begin{tabular}{|c|c|}
\hline Parameters & Details \\
\hline Problems diagnose & $\begin{array}{c}\text { Low yield of soybean due to } \\
\text { imbalance nutrition }\end{array}$ \\
\hline \multicolumn{2}{|c|}{ Technology selected for assessment } \\
\hline \multicolumn{2}{|c|}{$\begin{array}{c}\mathrm{T}_{1}: 100 \% \mathrm{NPK}+5 \text { t FYM ha } \\
\mathrm{T}_{2}: 100 \% \mathrm{NPK} \\
\mathrm{T}_{3}: 100 \% \mathrm{NK}+50 \% \mathrm{P} \\
\mathrm{T}_{4}: 100 \% \mathrm{NPK}-\mathrm{S} \\
\mathrm{T}_{5}: \text { Farmer's Practice }\end{array}$} \\
\hline Production system & Soybean- wheat \\
\hline Thematic area & Nutrient management \\
\hline Micro farming situation & Irrigated \\
\hline $\begin{array}{c}\text { Constants identified and } \\
\text { feedback for research work }\end{array}$ & $\begin{array}{c}\text { Facilities for soil testing are not } \\
\text { available in block level }\end{array}$ \\
\hline $\begin{array}{l}\text { Process for farmers } \\
\text { participation and their reaction }\end{array}$ & $\begin{array}{c}\text { Training, soil health camp, } \\
\text { demonstration, field day and } \\
\text { popular article }\end{array}$ \\
\hline Number of trails/ farmers & Six \\
\hline Crop & Wheat \\
\hline Variety & GW-366 \\
\hline
\end{tabular}

The recommended $\mathrm{N}, \mathrm{P}$ and $\mathrm{K}$ dose, based on initial soil test, was $120 \mathrm{~kg} \mathrm{~N}, 80 \mathrm{~kg} \mathrm{P}_{2} \mathrm{O}_{5}$ and $40 \mathrm{~kg} \mathrm{~K}_{2} \mathrm{O} \mathrm{ha}^{-1}$ for wheat. The sources of $\mathrm{N}, \mathrm{P}$ and $\mathrm{K}$ used were urea, single super phosphate and muriate of potash. During Rabi season, all the nutrients, viz. half dose of $\mathrm{N}+$ full dose of $\mathrm{P}$ and $\mathrm{K}$ were applied at the time of sowing. Whereas, remaining half dose of nitrogen in two split doses were applied as top dressing. Wheat (variety GW-366) was sown in the second week of November to first week of December during Rabi. Insects and diseases were kept under check following suitable control measures. Wheat was harvested at maturity and yield data were recorded after threshing. The soil samples were collected after harvest of crop from $0-15 \mathrm{~cm}$ depth were analyzed for different parameters by standard laboratory procedures.

\section{Results and Discussion}

\section{Yield analysis}

The data presented in Table-2 indicated that the treatment $\mathrm{T}_{1}-100 \% \mathrm{NPK}+\mathrm{FYM}$ produced the highest average yield $\left(4058 \mathrm{~kg} \mathrm{ha}^{-1}\right)$ followed by $\mathrm{T}_{2}-100 \%$ NPK which gave $3642 \mathrm{~kg} \mathrm{ha}^{-1}$ yield. The data clearly indicated that addition of integrated application of fertilizer with FYM was found to be beneficial for improving the productivity potential of wheat [8]. The lowest yield of wheat $\left(3210 \mathrm{~kg} \mathrm{ha}^{-1}\right)$ was recorded in $\mathrm{T}_{5}$-farmer's practice. Maximum increase in yield (26\%) was observed with $100 \%$ NPK + FYM over farmer's practice, followed by $13 \%$ increase in yield $(100 \%$ NPK) of wheat over farmer's practice. The data further showed that even the $50 \% \mathrm{P}$ application with $100 \%$ NK was found to be increased the yield for about $11 \%$ in wheat over farmer's practice. These results established the importance of $\mathrm{P}$ application and found to be a major fertility constraint in controlling productivity of crops grown especially in black soil [13].

\section{Extension gap}

Extension gap was calculated by subtracting farmer's practice yield from recommended practice. The difference of this gap is denoted that there is a sufficient chance to increase in wheat yield by adopting recommended technology. The data presented in table 3 , indicated that the treatment $\mathrm{T}_{1}-100 \% \mathrm{NPK}+\mathrm{FYM}$ had the highest average extension gap $\left(848 \mathrm{~kg} \mathrm{ha}^{-1}\right)$ followed by $\mathrm{T}_{2}-100 \% \mathrm{NPK}$ $\left(432 \mathrm{~kg} \mathrm{ha}^{-1}\right)$ and $\mathrm{T}_{3}-100 \% \mathrm{NK}+50 \% \mathrm{P}\left(365 \mathrm{~kg} \mathrm{ha}^{-1}\right)$. The lowest average extension gap $\left(195 \mathrm{~kg} \mathrm{ha}^{-1}\right)$ was recorded in $\mathrm{T}_{4}-100 \% \mathrm{NPK}-\mathrm{S}$. The results are in close conformity with results of [1] and they were reported that 36.66 per cent of the farmers had low and medium adopted use of recommended dose of fertilizers. These results are also in agreement with the findings of [7and 6]. 
Table 2. Grain Yield $\left(\mathrm{kg} \mathrm{ha}^{-1}\right)$ of wheat

\begin{tabular}{|c|c|c|c|c|c|c|c|}
\hline S. No. & Name of farmers & Village & $\mathbf{T}_{\mathbf{1}}$ & $\mathbf{T}_{\mathbf{2}}$ & $\mathbf{T}_{\mathbf{3}}$ & $\mathbf{T}_{\mathbf{4}}$ & $\mathbf{T}_{\mathbf{5}}$ \\
\hline 1 & Shri Ramesh Patel & Luhari & 4250 & 3750 & 3700 & 3550 & 3350 \\
\hline 2 & Smt Jayanti Patel & Luhari & 4050 & 3500 & 3550 & 3350 & 3220 \\
\hline 3 & Shri Hari Lal Patel & Gathora & 4200 & 3800 & 3700 & 3550 & 3370 \\
\hline 4 & Shri Santosh Yadav & Dhatera & 3800 & 3450 & 3350 & 3180 & 3020 \\
\hline 5 & Shri Pramod Jain & Kanthi & 3950 & 3600 & 3500 & 3350 & 3050 \\
\hline 6 & Shri Kamal Patel & Amkhera & 4100 & 3750 & 3650 & 3450 & 3250 \\
\hline \multicolumn{2}{|r|}{} & & 4058 & 3642 & 3575 & 3405 & 3210 \\
\hline & A Increase over farmers practices & & 26 & 13 & 11 & 6 & - \\
\hline
\end{tabular}

Table 3. Extension Gap

\begin{tabular}{|c|c|c|c|c|c|}
\hline Name of farmers & Village & $\mathbf{T}_{\mathbf{1}}$ & $\mathbf{T}_{\mathbf{2}}$ & $\mathbf{T}_{\mathbf{3}}$ & $\mathbf{T}_{\mathbf{4}}$ \\
\hline Shri Ramesh Patel & Luhari & 900 & 400 & 350 & 200 \\
\hline Smt Jayanti Patel & Luhari & 830 & 280 & 330 & 130 \\
\hline Shri Hari Lal Patel & Gathora & 830 & 430 & 330 & 180 \\
\hline Shri Santosh Yadav & Dhatera & 780 & 430 & 330 & 160 \\
\hline Shri Pramod Jain & Kanthi & 900 & 550 & 450 & 300 \\
\hline Shri Kamal Patel & Gurda pipariya & 850 & 500 & 400 & 200 \\
\hline Average & & 848 & 432 & 365 & 195 \\
\hline
\end{tabular}

\section{Technology gap}

Technological gap was calculated by subtracting recommended technological yield from yield capacity of particularly variety. This gap is express that there is need to guide and educate for adopting recommended technology. The data presented in table 4, indicated that the treatment $\mathrm{T}_{5}$-Farmer's Practices had the highest average technology gap $(2490 \mathrm{~kg}$ $\mathrm{ha}^{-1}$ ) followed by $\mathrm{T}_{4} 100 \%$ NPK-S (2295 kg ha $\left.{ }^{-1}\right), \mathrm{T}_{3}-100 \% \mathrm{NK}+50 \% \mathrm{P}\left(2125 \mathrm{~kg} \mathrm{ha}^{-1}\right)$ and $\mathrm{T}_{2}-100 \% \mathrm{NPK}\left(2058 \mathrm{~kg} \mathrm{ha}^{-1}\right)$. The lowest average technology gap $1642 \mathrm{~kg} \mathrm{ha}^{-1}$ was recorded in $\mathrm{T}_{1}-100 \% \mathrm{NPK}+\mathrm{FYM}$. The similar results were also supported by the scientists [3and 6].

Table 4. Technology Gap

\begin{tabular}{|c|c|c|c|c|c|c|}
\hline Name of farmers & Village & $\mathbf{T}_{\mathbf{1}}$ & $\mathbf{T}_{\mathbf{2}}$ & $\mathbf{T}_{\mathbf{3}}$ & $\mathbf{T}_{\mathbf{4}}$ & $\mathbf{T}_{\mathbf{5}}$ \\
\hline Shri Ramesh Patel & Luhari & 1450 & 1950 & 2000 & 2150 & 2350 \\
\hline Smt Jayanti Patel & Luhari & 1650 & 2200 & 2150 & 2350 & 2480 \\
\hline Shri Hari Lal Patel & Gathora & 1500 & 1900 & 2000 & 2150 & 2330 \\
\hline Shri Santosh Yadav & Dhatera & 1900 & 2250 & 2350 & 2520 & 2680 \\
\hline Shri Pramod Jain & Kanthi & 1750 & 2100 & 2200 & 2350 & 2650 \\
\hline Shri Kamal Patel & Gurda pipariya & 1600 & 1950 & 2050 & 2250 & 2450 \\
\hline \multicolumn{2}{|r|}{ Average } & 1642 & 2058 & 2125 & 2295 & 2490 \\
\hline
\end{tabular}

\section{Soil test values}

The result revealed that the soil $\mathrm{pH}$ recorded before sowing ranged between $6.5-7.2$, while $\mathrm{pH}$ value was found to be unchanged even at harvest of crop which ranged between 6.1 to 7.7. The EC values of the soil ranged between 0.16 to $0.21 \mathrm{dSm}^{-1}$ in soil before sowing. While, EC values were found to be unchanged at harvest of crops which ranged between 0.14 to $0.23 \mathrm{dSm}^{-1}$, indicate that imposition of different treatments had altered not change in soil EC. The application of fertilizer could not exhibit any adverse effect on the soil physico-chemical properties due to its inherent high buffering capacity. Similar finding have also been reported by [5]. The data also indicated (Table-5) that organic carbon content in soil found to increase with increasing levels of fertilizer addition application thereby, lower content was found in farmer's practice as compared to $100 \%$ NPK $+F Y M$ application followed by treatment receiving imbalanced fertilizer doses. The organic carbon content in soil indicated that the contribution of organic carbon 
content appeared due to decomposition of plant and root residues [9 and 4]. Similarly, the available N, P and K content in soil was found to be higher with $100 \%$ NPK + FYM treatment, however, lowest content was noted in farmer's practice.

Table 5. Soil test values of various farmers field

\begin{tabular}{|c|c|c|c|c|c|c|}
\hline \multirow{2}{*}{ Treatment } & \multirow{2}{*}{$\mathbf{p H}$} & \multirow{2}{*}{$\begin{array}{c}E C \\
\left(\mathbf{d S S}^{-1}\right)\end{array}$} & \multirow{2}{*}{$\begin{array}{c}\mathrm{OC} \\
\left(\mathrm{g} \mathrm{kg}^{-1}\right)\end{array}$} & \multicolumn{3}{|c|}{ Available Nutrients $\left(\mathrm{kg} \mathrm{ha}^{-1}\right)$} \\
\hline & & & & $\mathbf{N}$ & $\mathbf{P}$ & $\mathbf{K}$ \\
\hline \multicolumn{7}{|c|}{ Shri Ramesh Patel } \\
\hline $100 \%$ NPK +5 t FYM ha $^{-1}$ & 6.7 & 0.17 & 6.9 & 280 & 19.4 & 429 \\
\hline $100 \% \mathrm{NPK}$ & 6.6 & 0.16 & 6.8 & 275 & 17.9 & 425 \\
\hline $100 \% \mathrm{NK}+50 \% \mathrm{P}$ & 6.5 & 0.14 & 6.7 & 270 & 18.5 & 426 \\
\hline $100 \%$ NPK - S & 6.4 & 0.15 & 6.7 & 265 & 18.2 & 424 \\
\hline Farmer's Practice & 6.5 & 0.17 & 6.6 & 255 & 16.1 & 412 \\
\hline \multicolumn{7}{|c|}{ Smt Jayanti Patel } \\
\hline $100 \%$ NPK $+5 \mathrm{t} \mathrm{FYM} \mathrm{ha}^{-1}$ & 6.8 & 0.20 & 5.8 & 220 & 18.2 & 460 \\
\hline $100 \%$ NPK & 6.4 & 0.19 & 5.7 & 218 & 17.9 & 455 \\
\hline $100 \% \mathrm{NK}+50 \% \mathrm{P}$ & 6.6 & 0.18 & 5.6 & 216 & 18.1 & 456 \\
\hline $100 \%$ NPK - S & 6.5 & 0.19 & 5.5 & 214 & 17.9 & 440 \\
\hline Farmer's Practice & 6.2 & 0.16 & 5.4 & 217 & 16.4 & 421 \\
\hline \multicolumn{7}{|c|}{ Shri Hari Lal Patel } \\
\hline $100 \%$ NPK +5 t FYM ha $^{-1}$ & 6.6 & 0.19 & 5.4 & 210 & 18.2 & 540 \\
\hline $100 \% \mathrm{NPK}$ & 6.3 & 0.19 & 5.3 & 205 & 17.8 & 535 \\
\hline $100 \% \mathrm{NK}+50 \% \mathrm{P}$ & 6.3 & 0.18 & 5.2 & 207 & 18.1 & 530 \\
\hline $100 \%$ NPK - S & 6.4 & 0.21 & 5.1 & 203 & 16.7 & 529 \\
\hline Farmer's Practice & 6.1 & 0.22 & 4.9 & 201 & 15.5 & 505 \\
\hline \multicolumn{7}{|c|}{ Shri Santosh Yadav } \\
\hline $100 \%$ NPK +5 t FYM ha $^{-1}$ & 7.7 & 0.21 & 6.1 & 240 & 9.0 & 505 \\
\hline $100 \% \mathrm{NPK}$ & 7.3 & 0.19 & 6.0 & 235 & 8.8 & 501 \\
\hline $100 \% \mathrm{NK}+50 \% \mathrm{P}$ & 7.1 & 0.22 & 6.1 & 230 & 8.5 & 498 \\
\hline $100 \%$ NPK - S & 7.5 & 0.21 & 6.2 & 228 & 8.7 & 504 \\
\hline Farmer's Practice & 7.0 & 0.20 & 5.8 & 218 & 7.8 & 482 \\
\hline \multicolumn{7}{|c|}{ Shri Pramod Jain } \\
\hline $100 \%$ NPK $+5 \mathrm{t} \mathrm{FYM} \mathrm{ha}^{-1}$ & 7.5 & 0.22 & 7.6 & 274 & 15.8 & 457 \\
\hline $100 \% \mathrm{NPK}$ & 7.3 & 0.23 & 7.1 & 278 & 14.9 & 452 \\
\hline $100 \% \mathrm{NK}+50 \% \mathrm{P}$ & 7.1 & 0.19 & 7.3 & 265 & 15.3 & 439 \\
\hline $100 \%$ NPK - S & 7.4 & 0.22 & 7.2 & 270 & 15.1 & 431 \\
\hline Farmer's Practice & 7.1 & 0.19 & 6.9 & 255 & 14.1 & 423 \\
\hline \multicolumn{7}{|c|}{ Shri Kamal Patel } \\
\hline $100 \%$ NPK +5 t FYM ha $^{-1}$ & 7.6 & 0.20 & 6.8 & 260 & 12.4 & 675 \\
\hline $100 \% \mathrm{NPK}$ & 7.3 & 0.18 & 6.5 & 258 & 12.1 & 670 \\
\hline $100 \% \mathrm{NK}+50 \% \mathrm{P}$ & 7.2 & 0.19 & 6.3 & 256 & 12.3 & 673 \\
\hline $100 \%$ NPK - S & 7.3 & 0.18 & 6.6 & 250 & 12.0 & 657 \\
\hline Farmer's Practice & 7.0 & 0.15 & 6.1 & 240 & 11.6 & 645 \\
\hline
\end{tabular}

\section{HRD components}

Table 6. Human Resource Development Components

\begin{tabular}{|c|c|c|}
\hline HRD Components & Frequency & Beneficiaries \\
\hline Training & 03 & 72 \\
\hline Soil health camp & 1 & 36 \\
\hline Field day & 2 & 38 \\
\hline Popular articles & 3 & Mass \\
\hline Training hand out & 3 & 105 \\
\hline Kisan Mela & 1 & Mass \\
\hline
\end{tabular}

During the study period, Human Resources Development Components i.e. training, soil health camp, field day, popular articles, training handout and Kisan Mela were also taken to increase the farmers understanding and skill about the recommended practice on soil test crop response (Table 6). The similar results were also supported by the scientists [ 1 and 3$]$. They concluded that farmers are required HRD components to make aware about the associated activities.

\section{REFERENCES}

[1] Agrawal SB, Sharma DP, Bisen Rajani and Singh DK 2011. Attitude and adoption of farmers to use of biofertilizer. 
Abstract, National Seminar on Innovative Extension Approaches for Enhancing Rural Household Income, dated 27-29 Sept. 2011, held at JNKVV, Jabalpur (M.P.), p. 86.

[2] Anonymous. 2016. Agriculture Statistics at a glance, Department of Agriculture and co-operation, Ministry of Agriculture, Government of India, New Delhi.

[3] Bhatnagar RK, Dwivedi AK, Sachidanand B and Pahalwan DK 2011. Impact of integrated application of organic manure and chemical fertilizers on productivity of soybean, wheat and chickpea grown on vertisols of Madhya Pradesh. JNKVV Research Journal 45 (20): 231-234.

[4] Dwivedi AK and Dwivedi BS 2015. Impact of long term fertilizer management for sustainable soil health and crop productivity: Issues and challenges. JNKVV Research Journal 49 (3): 387-397.

[5] Dwivedi BS, Dwivedi AK and Sharma Abhishek 2017. Effect of Continuous Application of Inorganic Fertilizers and FYM on Soil Nutrient Status in a Vertisol. In Abst. Third International Conference on Bioresource and Stress Management held at State Institute of Agriculture Management, Jaipur, during 8-11th Nov., 2017, pp. 48.

[6] Dwivedi BS, Tiwari RK, Thakur RK and Pandey AK 2016. Effect of environment friendly soil testing tool on performance of soybean. Environment \& Ecology 32 (2): 446-450.

[7] Khan I M, Tiwari RK, Joshi RP and Singh Nirmala 2008. Impact analysis of FLD's and OFT's on integrated crop management techniques for soybean cultivation in Rewa,
Madhya Pradesh. JNKVV Research Journal 42 (2):163-165.

[8] Kumar Y, Singh SP and Singh VP. 2015. Efect of FYM and potassium on yield, nutrient uptake and economics of wheat in alluvial soil. Annals of Plant and Soil Research 17 (1): 100-103.

[9] Santhy P, Muthuvel P and Selvi D 2001. Status and impact of organic matter fractions on yield, uptake and available nutrients in a Long-Term Fertilizer Experiment. Journal of the Indian Society of Soil Science 49:281-285.

[10] Shewry PR. 2009. Wheat. Journal of Experimental Botany 60: $1537-1553$

[11] Singh D, Rana DS and Pandey RN 1998.Crop yield and changes in soil fertility status of a Typic Ustochreft under intensive cultivation and long term use of fertilizer. Proc. Nation Workshop Long Term Fertility Management Theory. Integrated Nutrient Supply System. IISS, Bhopal Pp.: 183-193.

[12] Thakur RK, Khatik SK and Dwivedi BS 2008. Combine effect of FYM, SSP and PSB on yield, P uptake and P content by using Radioisotope (SSS ${ }^{32} \mathrm{P}$ ) technique in rice. JNKVV Research Journal 42(2):119-122.

[13] Yang X., Yang, Y., Sun, B. and Zhang, S. 2011. Long-term fertilization effects on yield trends and soil properties under a winter wheat- summer maize cropping system. African J. Agric. Res., 6 (14): 3392-3401. 